\title{
EDUCATION IN THE EARLY CHILDHOOD TOWARDS ENERGY SAVING BEHAVIOUR
}

\author{
Upik Elok Endang Rasmani \\ PG PAUD FKIP Universitas Sebelas Maret \\ upikelok@staff.uns.ac.id
}

\begin{abstract}
The purpose of this study is to implement a culture of energy-saving behavior. It is based on the implementation of basic energy-saving values, including (1) the development of a green education curriculum through energy conservation teaching materials of Economical, Wise and Smart to Use Energy. Also, (2) it encourages energy-saving behaviours, such as turning off devices that use energy while not in use, including lamp and AC. This strategy needs to be practiced continuously with teachers' help to inculcate positive habits in children. The study uses a comparative approach which is often meant to describe the profound relationship and the influence between two or more facts and the object properties examined. A comparative study is used to determine the cause of behavioral differences or individual status. This study involves a follow-up to the correlation research.
\end{abstract}

Keywords: education, habituation, energy saving, early childhood

\section{EDUKASI PADA ANAK USIA DINI MENUJU PEMBIASAAN HEMAT ENERGI}

\begin{abstract}
Abstrak: Penelitian ini bertujuan untuk menerapkan budaya perilaku tanggung jawab hemat energi melalui penerapan dasar nilai-nilai hemat energi yang mencakup: (1) pengembangan kurikulum green education melalui materi konservasi energi (hemat, bijak dan cerdas menggunakan energy; (2) pengembangan konsep kebiasaan hidup hemat energi (pembelajaran kepada siswa dan siswa mampu berpartisipasi secara aktif) seperti terbiasa mematikan peralatan sumber energi (lampu, AC) ketika tidak digunakan yang dilakukan secara berlanjut dengan pendampingan dari guru kepada siswa sehingga akan menjadi sebuah kebiasaan positif yang tertanam sejak kecil untuk menggunakan energi yang efisien dan rasional. Penelitian ini menggunakan studi komparatif sebagimana yang dikemukakan Sugianto (2008) bahwa penelitian komparatif adalah suatu penelitian yang dilakukan untuk menggambarkan sekema hubungan dan pengaruh yang dalam dari dua atau lebih fakta-fakta dan sifatsifat obyek yang diteliti. Penelitian ini ditujukan untuk menentukan penyebab atau alasan adanya perbedaan perilaku atau status kelompok individu. Studi kausal komparatif ini merupakan tindak lanjut dari studi korelasional.
\end{abstract}

Kata Kunci: edukasi, pembiasaan, hemat energi, anak usia dini

\section{PENDAHULUAN}

Manusia membutuhkan energ
untuk mempertahankan dan mengembangkan hidupnya. Tanpa energi, segala yang ada di bumi akan mengalami stagnasi dalam perkembangannya, dan akhirnya akan berakhir dengan kematian. Semakin meningkatnya jumlah manusia, akan berimplikasi kepada semakin meningkatnya pula jumlah kebutuhan dan mobilitasnya (Hibbert, 2012) [1]. Hal ini tak dapat dipungkiri akan berdampak langsung terhadap konsumsi energi dalam pemenuhan kebutuhan dan aktivitasnya itu (Blagojevic, 2016) [2]. Cadangan energi yang paling banyak dikonsumsi manusia adalah bahan bakar minyak (BBM) yang berasal dari fosil (penambangan minyak bumi) dan energi listrik (Turley, 
2015) [3].

Dalam era globalisasi dan Industri 4.0, hemat energi listrik merupakan langkah sederhana untuk mencegah sikap pemborosan energi. Pembelajaran hemat energi listrik harus ditanam mulai dini atau awal dan dimulai sejak anak anak. Gita (2016) [4] mengatakan bahwa "Kita menyadari bahwa perubahan perilaku adalah hal yang paling mudah dan murah, tetapi sangat sulit untuk dilaksanakan. Untuk mengubah perilaku diperlukan usaha yang sungguh-sungguh dan berulang," ujar Kasubdit Kerjasama Konservasi Energi, Direktorat Energi Baru Terbarukan dan Konservasi Energi Kementerian Energi dan Sumber Daya Mineral (ESDM).

Pembelajaran hemat energi inilah yang akan dijadikan anak untuk belajar kedepannya. Salah satunya dalam hal energy, anak-anak yang tumbuh di dunia modern seperti ini, lebih sering menggunakan alat-alat elektronik yang menghabiskan energi listrik (Suhana) [5]. Seolah-olah mereka tak pernah bisa lepas dari gadget, televisi, dan lain sebagainya. Sebagai orangtua haruslah memberikan pemahaman pentingnya menghemat energi. Sedangkan mengajarkan anak menghemat listrik itu sangat membantu menjaga lingkungan di saat ini dan masa depan. Melakukan penghematan energi juga berpengaruh pada pemanasan global dan tagihan listrik di rumah (Aguirre-Bielschowsky, 2017) [6].

"Energi merupakan komoditi strategis bagi suatu bangsa, Indonesia dikaruniai berbagai jenis sumber energi seperti minyak bumi, gas bumi dan batubara. Sumber energi terbarukan seperti matahari, angin, tenaga air, panas bumi dan biomassa juga berlimpah. Sumber energi ini mayoritas ditransformasi menjadi listrik, namum sayangnya Indonesia masih tergolong boros dalam menggunakan energi dan listrik," kata Gita (2016) [4] Kasubdit Kerjasama Konservasi Energi, Direktorat Energi Baru Terbarukan dan Konservasi Energi Kementerian Energi dan Sumber Daya Mineral (ESDM).

Menurut Utomo (2019) [7] selaku Wakil Ketua Dewan Pakar Masyarakat Ketenagalistrikan Indonesia, kesadaran masyarakat Indonesia perlu ditumbuhkan bahwa cadangan energi di Indonesia terbatas, selama ini terjadi persepsi dimasyarakat bahwa sumber daya energi kita melimpah sehingga perilaku mereka dalam mengkonsumsi energi menjadi boros dan tidak efisien. Kementerian ESDM (2016) [8] menyatakan, secara umum masalah pemborosan energi, 80 persennya disebabkan oleh faktor manusia dan sisanya 20 persen disebabkan oleh faktor teknis. Keberhasilan penggunaan energi secara efisien sangat dipengaruhi oleh perilaku, kebiasaan, kedisplinan dan kesadaran akan hemat energi.

Menyorot konsumsi energi Indonesia, berdasarkan data Kementerian ESDM (2016) [9] disebutkan, dalam beberapa tahun terakhir pertumbuhan konsumsi energi Indonesia mencapai 7 persen per tahun, sementara pertumbuhan konsumsi energi dunia hanya 2,6 persen per tahun. Djadjang Sukarna (2018) [10], menjelaskan, konsumsi energi yang tinggi ini menimbulkan masalah dan ketimpangan, yaitu terjadinya pengurasan sumber daya fosil seperti minyak dan gas bumi 
serta batu bara yang lebih cepat, jika dibandingkan dengan penemuan cadangan baru. Jika kondisi ini dibiarkan terus, Indonesia akan mengalami kehabisan energi pada tahun 2030 .

Untuk mengatasi permasalahan tingginya tingkat konsumsi energi listrik di Indonesia, perlu adanya penanaman sikap dan tanggung jawab untuk menghemat energi, khususnya ditujukkan untuk anak usia dini. Hal ini dimaksudkan agar anak-anak memiliki sikap tanggung jawab sejak dini untuk menjaga lingkungannya dan sikap peduli terhadap persediaan energi dimasa depan. Contoh sikap hemat energy paling sederhana adalah mematikan lampu setelah menggunakan ruangan, mengganti lampu pijar dengan lampu hemat energi. Ini adalah hal-hal sederhana yang kadang tidak kita sadari, tetapi kalau kita bisa merubah perilaku ini maka kita bisa menghemat energi dalam jumlah yang cukup besar.

Berdasarkan paparan latar belakang masalah di atas maka dalam penelitian ini diajukan rumusan masalah sebagai berikut: Bagaimana cara untuk meningkatkan tanggung jawab perilaku hemat energi pada anak usia dini? Bagaimana hasil penerapan kegiatan peningkatan tangggung jawab perilaku hemat energi pada anak usia dini? Tujuan penelitian ini adalah untuk meningkatkan tanggungjawab melalui hemat enegi pada anak usia dini.

\section{METODE PENELITIAN}

Penelitian ini dilaksanakan di TK WARGA Surakarta, alasan pemilihan tempat penelitian adalah: a) Mempertimbangkan kemudahan kerjasama dengan pihak sekolah dan objek yang diteliti, b) Sekolah tersebut belum pernah digunakan sebagai objek penelitian sejenis sehingga dapat

\section{Hal. 33-38 \\ ISSN 2684-7442 \\ https://jurnal.uns.ac.id/ecedj}

menghindari terjadinya penelitian ulang, c) Terdapat permasalahan dalam hal tanggung jawab anak tekait hemat energi. Jenis penelitian ini adalah penelitian komparatif, merupakan suatu rumusan masalah penelitian yang membandingkan keberadaan satu variabel atau lebih pada dua atau lebih sampel yang berbeda, atau pada waktu yang berbeda.

Sugianto (2008) [11] mengemukakan bahwa penelitian komparatif adalah suatu penelitian yang dilakukan untuk menggambarkan sekema hubungan dan pengaruh yang dalam dari dua atau lebih fakta-fakta dan sifat-sifat obyek yang diteliti. Penelitian ini ditujukan untuk menentukan penyebab atau alasan adanya perbedaan perilaku atau status kelompok individu. Studi kausal komparatif ini merupakan tindak lanjut dari studi korelasional. Jika korelasional menggambarkan derajat obyek yang diteliti, maka studi kausal komparatif menggambarkan sedemikian rupa hubungan sebab akibat.

Melalui metode ini peneliti bermaksud menggambarkan atau mendeskripsikan objek masalah yang berkaitan dengan upaya meningkatkan tanggung jawab perilaku hemat energy pada anak usia dini di TK Warga Surakarta. Penelitian dilaksanakan pada semester genap dan ganjil tahun ajaran 2020 dalam jangka waktu 10 bulan, yaitu pada bulan Februari 2020 sampai dengan November 2020. Jenis-jenis kegiatan yang dilakukan meliputi penyusunan dan pengajuan proposal, pelaksanaan kegiatan, analisis data dan seminar hasil penelitian dan penyusunan laporan serta menggunakan perpaduan snowball sampling yang mana dalam penelitian ini informasi bergulir terus menerus terkait pelaksaaan 
pembiasaan tanggung jawab perilaku hemat energy pada anak sehingga informasi diinginkan dapat diperoleh secara penuh oleh peneliti.

\section{HASIL DAN PEMBAHASAN}

Pendidikan budaya hemat energi dapat dikembangkan melalui kerjasama kementerian (Ristekdikti, Menhan, ESDM) dalam mengajak lembagalembaga pemerintahan, pendidikan dan kemasyarakatan melalui aksi Green Team. Aksi ini merupakan program perubahan perilaku agar lebih mencintai Indonesia melalui peranan dan sikap efisien di lingkungan sekitar, dalam upaya peningkatan efisiensi dan konservasi di berbagai sektor pengguna energi final, seperti sektor rumah tangga, komersil, industri dan transportasi, sehingga tercipta perubahan perilaku budaya hemat energi secara berkelanjutan.

Pemerintah melalui kementerian ESDM menyediakan fasilitas jasa pelayanan Energy Efficiency and Conservation Clearing House Indonesia (EECCHI) yakni Energy Saving with Changing Behavior (SWITCH) Behavior, melalui langkah kegiatan:

1. Mendapatkan dukungan dan komitmen pelaksanaan hemat energi;

2. Mengidentifikasi situasi kebutuhan energi yang banyak digunakan;

3. Perencanaan program hemat energi;

4. Penerapan program hemat energi;

5. Evaluasi hasil program hemat energi serta keberlanjutan budaya hemat energi dalam organisasi.

Kesempatan

dalam memperjuangkan keberlanjutan energi masa depan melalui kesadaran hemat, bijak dan cerdas dalam penerapan pendidikan nilai-nilai budaya hemat energi bagi semua civitas akademika pendidikan. Baik pengajar (tenaga pendidik) maupun para murid-muridnya (tenaga terdidik) serta penerapan konsep penerapan silabus pendidikan berupa mata pelajaran unggulan yakni green education dalam konservasi dan penghematan energi.

Para pengajar di bidang pendidikan akan diberikan dukungan dan komitmen oleh EECCHI berupa materi pelatihan (training), workshop, buku panduan dan tantangan kompetisi hemat energi antar sekolah, pemberian penghargaan atas sekolah yang berhasil memiliki civitas akademika yang bertindak bijak, cerdas, hemat energi dengan efisiensi energi, sehingga dapat menerapkan metode pembelajaran nilai-nilai budaya hemat energy disekolah.Para tenaga pendidik harus memiliki kebiasaan melakukan hal-hal yang hemat dalam penggunaan energi untuk ketahanan energi, mengetahui sumber penggunaan energi terbesar hasil identifikasi biaya kebutuhan energi yang tergolong boros energi, serta memilih penggunaan peralatan energi yang telah memperoleh labelisasi hemat energi dilingkungan sekolah.

Pengajaran yang efektif dari tenaga pendidik adalah pengajaran yang memberikan contoh tindakan secara konsisten dan komitmen bahwa energi berkelanjutan merupakan tanggung jawab bersama dan hanya akan tercapai bila semua civitas akademika menginginkan keberlanjutan energi tersebut bagi keamanan energi di Indonesia. Pengajaran sejak dini di tingkat sekolah, dimula dari membiasakan murid jenjang pendidikan anak usia dini, Taman Kanak-Kanak (TK) untuk melakukan hal-hal kecil yang dapat menghemat energi, seperti mematikan peralatan sumber energi (keran air, lampu, AC) ketika tidak digunakan yang dilakukan secara berlanjut dengan pendampingan dari tenaga pendidik, sehingga akan menjadi sebuah kebiasaan positif yang tertanam sejak kecil. 
Penghematan listrik dapat dilakukan dengan cara mematikan peralatan elektronik yang tidak digunakan seperti lampu, komputer/laptop, AC, kipas angin. Penghematan listrik pada lampu: (1) melakukan penempelan stiker pengingat yang tersedia di dekat saklar lampu; (2) mempergunakan lampu hemat energi (LHE) dan mengurangi pemakaian lampu bohlam/ pijar. Lampu jenis ini menggunakan energi 80 persen lebih sedikit dan berumur sampai 10 kali lipat dibandingkan lampu biasa. Harganya sedikit lebih mahal, tetap sangat hemat listrik; (3) membuka tirai jendela di siang hari agar sinar matahari bisa menerangi hingga ke bagian dalam rumah; (4) membersihkan lampu secara berkala agar penerangan bisa lebih maksimal; (5) menyesuaikan jumlah titik dan daya (watt). Menggunakan banyak titik lampu dengan daya rendah akan lebih hemat energi dan baik untuk kondisi mata dibandingkan dengan menggunakan 1 titik dengan daya besar; (6) menghindari kontrol penerangan pada 1 titik saja bila ruangan yang harus dicakup sangat luas.

Penghematan listrik pada AC; (1) mematikan AC jika ruangan tidak dipergunakan; (2) menutup jendela dan pintu ketika AC sedang berada pada posisi on; (3)mengatur suhu AC sesuai kebutuhan sekitar $24-27^{\circ} \mathrm{C}$ karena semakin dingin suhu maka semakin besar konsumsi listriknya; mempergunakan kaca film pada jendela ruangan; (5) menggunakan timer untuk mengatur pemakaian AC; (6) membersihkan AC secara berkala; (7) menggunakan kapasitas AC sesuai dengan volume ruangan; (8) memasang dan menggunakan ceiling fan untuk membantu pemerataan suhu ruangan; (9) menghindari penempatan peralatan elektronik didekat unit AC; (10) menggunakan AC hemat energi dengan teknologi inverter.

\section{SIMPULAN}

Penerapan nilai-nilai budaya hemat energi mencakup: (a) penerapan silabus pendidikan berupa mata pelajaran green education dalam konservasi dan penghematan energi di institusi pendidikan; (b) pengembangan konsep kebiasaan hidup hemat energi secara dua arah (pembelajaran dari siswa ke siswa sehingga partisipasi siswa secara aktif) seperti mematikan peralatan sumber energi (keran air, lampu, AC) ketika tidak digunakan yang dilakukan secara berlanjut dengan pendampingan dari tenaga pendidik, sehingga akan menjadi sebuah kebiasaan positif yang tertanam sejak kecil untuk menggunakan energi yang efisien dan rasional; (c) Pemerintah melalui kementerian ESDM telah mengembangkan program Energy Saving with Changing Behavior (SWITCH) Behaviordan buku panduan langkah yang efektif dalam pengembangan program "potong 10\%" dalam rangka penerapan budaya hemat energi.

\section{DAFTAR PUSTAKA}

[1] Hibbert, "Understanding Energy Cultures," Underst. Energy Cult., pp. 1-7, 2012.

[2] M. R. Blagojević and A. Tufegdžić, "The new technology era requirements and sustainable approach to industrial heritage renewal," Energy Build., 2016.

[3] M. Turley and S. Sayce, "Energy performance certificates in the context of sustainability and the impact on valuations," J. Prop. Invest. Financ., 2015.

[4] Yulianingsih, "Menghemat Energi dari Sekolah," Senin 25 Jul 2016 14:00 WIB, 2016. 
[Online]. Available: https://www.republika.co.id/berita /otomotif/mobil/12/08/11/koran/k esra/16/07/25/oauzgb13menghemat-energi-dari-sekolah. [Accessed: 25-Jan-2020].

[5] M. Suhana, "Influence of Gadget Usage on Children's SocialEmotional Development," 2018.

[6] I. Aguirre-Bielschowsky, R. Lawson, J. Stephenson, and S. Todd, "Energy literacy and agency of New Zealand children," Environ. Educ. Res., vol. 23, no. 6, pp. 832-854, 2017.

[7] F. Yudianto, "Pembelajaran Dini Hemat Energi Listrik," 15 Agustus 2019, 2019. [Online]. Available:

https://duta.co/pembelajaran-dinihemat-energi-listrik. [Accessed: 25-Jan-2020].

[8] W. Budiyanto, "Perilaku Hemat Energi Harus Ditanamkan Sejak Dini," Minggu, 24 Juli 2016, 2016. [Online]. Available: http://infopublik.id/read/164728/p erilaku-hemat-energi-harusditanamkan-sejak-dini.html. [Accessed: 25-Jan-2020].

[9] Ferial, "Nilai Hemat Energi Harus Ditanamkan Sejak Dini," Senin, 25 Juli 2016, 2016. [Online]. Available:

http://ebtke.esdm.go.id/post/2016/ 07/25/1290/nilai.hemat.energi.har us.ditanamkan.sejak.dini.

[Accessed: 25-Jan-2020].

[10] Rusyan, "Hemat Listrik Sejak Usia Dini," Kamis, 6 Desember 2018, 2018. [Online]. Available: jabarekspres.com/2018/hematlistrik-sejak-usia-dini/3/.

[Accessed: 26-Jan-2020].
[11] Sugiyanto. (2008). Modelmodel pembelajaran inovatif. Surakarta: UNS Press. 